\title{
Framing PIGS: patterns of racism and neocolonialism in the Euro crisis
}

\author{
Jonas Van Vossole
}

To cite this article: Jonas Van Vossole (2016) Framing PIGS: patterns of racism and neocolonialism in the Euro crisis, Patterns of Prejudice, 50:1, 1-20, DOI: 10.1080/0031322X.2015.1128056

To link to this article: http://dx.doi.org/10.1080/0031322X.2015.1128056

册Published online: 19 Jan 2016.

Submit your article to this journal $\pi$

III Article views: 248

Q View related articles $\sqsubset$

View Crossmark data \lceil

4 Citing articles: 2 View citing articles 


\title{
Framing PIGS: patterns of racism and neocolonialism in the Euro crisis
}

\section{JONAS VAN VOSSOLE}

\begin{abstract}
Van Vossole's article explores the racist framing of the peripheral member states of the European Union, the PIGS (Portugal, Ireland (and/or Italy), Greece and Spain). It demonstrates a strong connection between the processes of racialization and depoliticization, as well as the return of colonial dynamics in the Eurozone. Side-stepping political economy and history, the culturalization of politics perfectly complements the 'post-political' neoliberal hegemony. Political and media discourses reproduce it in both populist and corporate interests. The culturalization of politics reduces the differences between centre and periphery to certain 'cultural characteristics and habits', as reflected in stereotypes of laziness, non-productivity, corruption, wasteful spending and lying. These make it possible to blame the PIGS for the current crisis, legitimizing drastic austerity measures and a loss of sovereignty. The loss of sovereignty shows remarkable similarities with what Kwame Nkrumah defined as neocolonialism: the continuation of colonial power relations through processes of economic dependence, conditional aid and cultural hegemony. While this problematic only resurfaced during the recent Euro crisis, Van Vossole discusses how today's racist discourses and neocolonial politics have their roots in the past, particularly in anti-Irish and anti-Mediterranean racism and in the (semi-)colonial position of the PIGS in the British and Ottoman empires. Besides structural violence against the periphery, a major consequence of this racialization is that it jeopardizes any possibility of further democratic political integration on the basis of a common European identity.
\end{abstract}

KEYWORDS austerity, depoliticization, Euro crisis, neocolonialism, neoliberalism, periphery, PIGS, racialization

$T$ his article addresses a surprisingly under-researched issue, namely, racism towards the PIGS: Portugal, Ireland (and/or Italy), Greece and Spain. By racism, I mean 'an expression of racially predicated or manifested social and political relations of domination, subordination and privilege', in which race refers to a socially fabricated political discourse 'through which differences... may be named and explained', ${ }^{1}$ as well as being naturalized and

1 David Theo Goldberg and John Solomos, 'General introduction', in David Theo Goldberg and John Solomos (eds), A Companion to Racial and Ethnic Studies (Oxford and Malden, MA: Blackwell Publishers 2002), 4, 3. 
dehistoricized. ${ }^{2}$ The accusation of 'racism' has emerged regularly during recent protests against austerity but, apart from Yiannis Mylonas's discourse analysis of the German popular press reporting of the Greek default, ${ }^{3}$ and a discussion by Luís Capucha et al. about the pejorative character of the term 'PIGS', ${ }^{4}$ academic work on the subject continues to be very limited. This is even more surprising considering its relevance to current political developments in the Eurozone.

The objective of this article is not to produce a representative sample of racist discourses about the peripheral countries. Rather what follows is an interdisciplinary analysis of how the current racial framing within the European Union reflects an interaction between race, (neo)colonialism and capitalist development. The following discussion offers a general description of the racial frame and its reproduction. It analyses the role of electoral processes and media discourses, both at the core and the periphery, and includes some illustrative examples.

The opposition between core and periphery - as defined in world-systems analysis ${ }^{5}$-is used as the main analytical framework for understanding the dynamics of the Euro crisis. Due to its symbolic importance for the racial framing of the crisis-ridden countries, the concept of periphery is often substituted by the term 'PIGS' in mainstream political and media discourses. The term 'PIGS' is a common abbreviation in both popular and scholarly discourses, derived from the initial letters of the countries suffering from the debt crisis: Portugal, Ireland, Greece and Spain, with Italy sometimes replacing Ireland. The term was first used in the Financial Times in 2008 in an article about the economic situation in Southern Europe entitled 'Pigs in muck', ${ }^{6}$ appearing thereafter in publications such as Newsweek and The Economist. ${ }^{7}$

In what follows, I will first describe the theoretical framework I use to analyse the reproduction of racism in the context of neoliberal hegemony:

2 John Solomos, 'Beyond racism and multiculturalism', Patterns of Prejudice, vol. 32, no. 4, 1998, 45-62.

3 Yiannis Mylonas, 'Media and the economic crisis of the EU: the "culturalization" of a systemic crisis and Bild-Zeitung's framing of Greece', TripleC (Communication, Capitalism \& Critique): Open Access Journal for a Global Sustainable Information Society, vol. 10, no. 2, 2012, 646-71.

4 Luís Capucha, Pedro Estêvão, Alexandre Calado and Ana Rita Capucha, "The role of stereotyping in public policy legitimation: the case of the pigs label', Comparative Sociology, vol. 13, no. 4, 2014, 482-502.

5 Immanuel Wallerstein, 'The itinerary of world-systems analysis; or, how to resist becoming a theory', in Joseph Berger and Morris Zelditch, Jr (eds), New Directions in Contemporary Sociological Theory (Lanham, MD and Oxford: Rowman \& Littlefield Publishers 2002), 358-76.

6 'Pigs in muck', Financial Times, 31 August 2008.

7 Juliane von Reppert-Bismarck, 'Why PIGS can't fly' (the title was changed to 'Why Southern Europe's economies don't compete' in 2015), Newsweek, 28 June 2008; 'Ten years on, beware a porcine plot', The Economist, 5 June 2008. 
the depoliticization and culturalization of difference. In the second section I discuss the historical origins of the racist discourse and how they relate to current discourses about the crisis. The third section discusses how such discourses are present in the contemporary political/electoral processes and in the popular media. The last section refers to the work of Kwame Nkrumah to discuss how these discourses are intertwined with a new kind of colonialism within the EU. ${ }^{8}$

\section{Depoliticization and dehumanization: the conditions of reproduction}

The last decades have been marked by a post-political, neoliberal hegemony. Such a hegemony forecloses ideological conflict through a consensus of enlightened technocrats. ${ }^{9}$ It has manifested itself in all the dominant ideological currents of these decades: from the straightforward neoliberalism of the liberal right, to the new regionalisms and on to the 'official', 'social', 'multiculturalist' opposition of the third-way 'left'. ${ }^{10}$ In the field of economics, it is expressed in the dominance of neoclassical, behavioural and experimental models. ${ }^{11}$ Particularly in the former, 'the economy' is reified and serves as a legitimation of capitalist social relations. ${ }^{12}$ Assuming that unevenness in development is automatically resolved through market mediation, problems of convergence are automatically blamed on inefficient 'economic' management. By restricting the focus on to aspects such as networking, social capital, innovation, reciprocity and trust, success and competitiveness, rather than considering power structures and injustice, even moderate neoliberal approaches 'individualize' cities and regions. By introducing emotional and personal vocabularies, political debate is emptied: Costis Hadjimichalis speaks of 'ideology through erasure' ${ }^{13}$ Class and geographic differences therefore become unmentionable, as are unequal trade, inequality, social justice and solidarity. Arguments pointing to different structural politicaleconomic causes of the crisis, based on theories of political geography, ${ }^{14}$

8 Kwame Nkrumah, Neo-Colonialism: The Last Stage of Imperialism (New York: International Publishers 1965).

9 Slavoj Žižek, The Ticklish Subject: The Absent Centre of Political Ontology (London: Verso 2000), 198.

10 Costis Hadjimichalis, ‘Uneven geographical development and socio-spatial justice and solidarity: European regions after the 2009 financial crisis', European Urban and Regional Studies, vol. 18, no. 3, 2011, 254-74.

11 Ana Cordeiro Santos, 'Behavioural and experimental economics: are they really transforming economics?', Cambridge Journal of Economics, vol. 35, no. 4, 2011, 705-28.

12 Slavoj Žižek, 'A permanent economic emergency', New Left Review, no. 64, JulyAugust 2010, 85-95.

13 Hadjimichalis, 'Uneven geographical development and socio-spatial justice and solidarity'.

14 Ibid. 
optimal currency area theory, ${ }^{15}$ Marxist crisis theory or neo-Keynesian theory, ${ }^{16}$ therefore, have largely been excluded from the public domain. ${ }^{17}$

Re-engaging with a Schmittean conception of 'the political', a range of critical academics - such as Chantal Mouffe, Slavoj Žižek, Jacques Rancière, Wendy Brown and Erik Swyngedouw-have developed the theoretical concept of depoliticization, which is characterized by Swyngedouw as the externalization of problems that are integral to or inherent in the relations of global neoliberal capitalism. ${ }^{18}$ The 'enemy' is continuously externalized and disembodied. Political phenomena are removed from any understanding of their historical roots or any recognition of the powers that produce and shape them. This theorization of depoliticization as the reduction of historically induced suffering into 'difference' is best developed by Wendy Brown. ${ }^{19}$ The foreclosed 'political' thus returns in the guise of new forms of racism generated during the process of political culturalization. ${ }^{20}$ The culturalization of politics - or 'culture talk', as Mahmood Mandani calls it ${ }^{21}$ - is the assumption 'that every culture has a tangible essence that defines it and explains politics as a consequence of that essence'. ${ }^{22}$ 'The culturalization of politics analytically vanquishes political economy, states, history, and international and transnational relations. It eliminates colonialism, capital, caste or class stratification, and external political domination from accounts of political conflict or instability. $^{23}$ Accordingly, the liberal hegemony reduces everything that does not fit in the liberal framework to something called 'culture', effectively positioning it as necessarily antagonistic to its principles, unless it is appropriated, unless, that is, culture is literally 'liberalized' through privatization and individualization. The liberal hegemony can only do this by neglecting its own 'culture' and historical essence: in short, liberalism becomes 'the culture' of the dominant capitalist classes of the world-system. ${ }^{24}$

15 Paul De Grauwe, Crisis in the Eurozone and How to Deal with It, CEPS Policy Brief, no. 204, 15 February 2010.

16 Paul Krugman, 'Eurozone problems', 30 January 2012, on Paul Krugman's blog 'The Conscience of a Liberal', available on the New York Times website at http://krugman. blogs.nytimes.com/2012/01/30/eurozone-problems (viewed on 6 November 2015).

17 Hadjimichalis, 'Uneven geographical development and socio-spatial justice and solidarity'.

18 Erik Swyngedouw, 'Impossible "sustainability" and the postpolitical condition', in Rob Krueger and David Gibbs (eds), The Sustainable Development Paradox: Urban Political Economy in the United States and Europe (New York and London: Guilford Press 2007), 13-40 (31).

19 Wendy Brown, 'Tolerance as a discourse of depoliticization', in Wendy Brown, Regulating Aversion: Tolerance in the Age of Identity and Empire (Princeton, NJ: Princeton University Press 2008), 1-25.

20 Žižek, The Ticklish Subject, 199.

21 Mahmood Mamdani, Good Muslim, Bad Muslim: America, the Cold War, and the Roots of Terror (New York: Three Leaves Press 2004).

22 Brown, 'Tolerance as a discourse of depoliticization', 20.

23 Ibid.

24 Ibid. 
Going a step further, some pro-austerity discourses even associate these antagonistic 'cultures' with animality, further 'naturalizing' socioeconomic positions. Since the ascendance of universalist humanism in Western European thought, animality - its negation-has systematically been used to frame socioeconomic realities in categories of (despised) animal nature and (morally superior) human culture, and to express difference and hierarchy in the rhetorics of race, class, gender and other identity constructs in western cultures. ${ }^{25}$ The term 'PIGS' falls into this category, reducing the peripheral countries to beasts.

\section{The historical origin of the peripheral racism}

The contemporary racist culturalist framework is built on a historical racialization of Southern and peripheral Europe. Racism seemed to be dormant during past decades of growth and relative prosperity, and with the discursive, economic and political integration of the South into Europe. But Barnor Hesse argues that the signifier of Europe itself is a historically constitutive logic of race in the process of colonization. ${ }^{26}$ Europe is therefore a contingent discursive boundary between Europe and non-Europe that defines civilization and legitimized colonialism. As Europe as a subject exists and is based on these contingent discursive boundaries defining constitutive outsides, the periphery of Europe is continuously caught in a struggle with its boundaries, a struggle to be part of Europe and periods of exclusion and racialization. The anti-peripheral racism historically has had two pillars: anti-Mediterranean racism and anti-Irish racism.

For centuries Northern Europeans have described Mediterranean peoples as lazy. Some locate the origin of this cultural imaginary in the transition to the so-called second modernity, when the core of the world-system and its ideological centre moved from the Iberian peninsula to Northwestern Europe; ${ }^{27}$ others point to the Napoleonic wars as the crucial moment in the constitution of the Mediterranianist image. ${ }^{28}$ Consistent with nineteenth-century racist ideology, Western Europeans have been classified on a hierarchical scale that moves upward from dark-skinned and passionate Southern Europeans to fair-skinned and reasonable Northerners. ${ }^{29}$ This scale sought to present

25 Kay Anderson, “"The beast within”: race, humanity, and animality', Environment and Planning D: Society and Space, vol. 18, no. 3, 2000, 301-20.

26 Barnor Hesse, 'Racialized modernity: an analytics of white mythologies', Ethnic and Racial Studies, vol. 30, no. 4, 2007, 643-63.

27 Boaventura de Sousa Santos, Portugal: Ensaio contra a autoflagelação (Lisbon: Almedina 2012).

28 Michael Herzfeld, 'The horns of the Mediterraneanist dilemma', American Ethnologist, vol. 11, no. 3, 1984, 439-54.

29 David Theo Goldberg, 'Modernity, race, and morality', Cultural Critique, no. 24, Spring 1993, 193-227. 
European culture as 'pure' in origin and, especially, free from Oriental influences. Although this racist ideology recognized modern Greeks as descendants of the classical Hellenes - the 'cradle' of western civilization-it never granted them full 'European' status. Having spent four centuries under Ottoman rule, their culture would, it was supposed, have been corrupted by Oriental influences and stagnated. ${ }^{30}$ A similar baleful effect was attributed to the centuries of Arab rule in the Iberian peninsula.

The notion of the 'Mediterranean' was constructed in contrast with the 'European' ${ }^{31}$ The culturalization of the Mediterranean, or Mediterraneanization, has been characterized by exoticism. For centuries, millions of Northern Europeans have associated the word 'Mediterranean' with an eternal dream of exotic pleasure, poetry, visual art and music. Its people are apparently what Northerners are not: talkative, emotional, passionate, suntanned. Nowadays, the term 'Mediterranean' has developed into more of a folk-concept as a result of tourism and a general interest in roots and tradition. ${ }^{32}$ Mass tourism-a consumer activity mainly practised by citizens of the Global North ${ }^{33}$-has commoditized this interest in 'exotic' cultural diversity, now reified as a known consumable product, ${ }^{34}$ as if the Mediterranean world were a historical theme park. ${ }^{35}$

Such racist imaginary has historically been strengthened by the mutual migratory relations between periphery and core. In the South, the huge emigration wave of the 1960s, the consequence of politically repressive regimes, harsh poverty and a lack of prospects for economic development, has been repeating itself recently. In the 'highly developed' receiving countries, migrants have frequently been confronted with racist attitudes and treated as second-class citizens, to such an extent in the Netherlands, for example, that 'black people' from the former colonies tend to consider the Southerners as black, due to the similar experiences of colonial and Mediterranean immigrants. ${ }^{36}$

This Mediterraneanization has not been restricted to popular discourses; it has also infiltrated the social sciences, anthropology in particular. ${ }^{37}$ Before the popularization of the concept of PIGS by the Financial Times during the recent crisis, notions of the 'exotic' (Club Med) and of PIGS already existed in

Vassos Argyrou, Tradition and Modernity in the Mediterranean: The Wedding as Symbolic Struggle (Cambridge: Cambridge University Press 2005).

31 Herzfeld, 'The horns of the Mediterraneanist dilemma'.

32 Jonas Frykman, 'Culturalization of the Mediterranean space', Narodna umjetnost: Croatian Journal of Ethnology and Folklore Research, vol. 36, no. 1, 1999, 283-6.

33 John Urry, Consuming Places (London and New York: Routledge 1995).

34 Mylonas, 'Media and the economic crisis of the EU', 663.

35 Frykman, 'Culturalization of the Mediterranean space'.

36 Philomena Essed, Understanding Everyday Racism: An Interdisciplinary Study (Newbury Park, CA, London and New Delhi: Sage Publications 1991).

Herzfeld, 'The horns of the Mediterraneanist dilemma'. 
economic discourses during the 1980s and 1990s. ${ }^{38}$ At the same time the comparative tradition, the mainstream school of political science, has tended to categorize the South as the undemocratic part of Europe-with Spain, Portugal and Greece having experienced military, fascist dictatorships until the 1970s, a categorization based on cultural values and economic underdevelopment.

Ireland and Italy occupy somewhat different positions, which partially explains why they are each sometimes substituted in the acronym PIGS. While not having the same history of Mediterraneanization, the Irish people have undergone a long period of racialization, and religious and racial discrimination, mainly by the British. ${ }^{39}$ Its history is marked by emigration waves associated with famines and economic hardship, often making them second-class citizens in the British Empire. Even the Irish have a 'black' identity: according to a widespread popular myth, the 'Black Irish' are descendants of Spanish sailors. ${ }^{40}$

The case of Italy is a very particular one. More than the others, Italy has been part of the core of industrialized Europe, and was one of the founding members of the European Community but, from a political economic perspective, the country has historically been divided in two. While it is the industrialized North that has been part of the core of the European economy, the South - the Mezzogiorno - has been economically underdeveloped and poor. The South has experienced comparable processes of racialization by the northern industrial elite; its language has been widely seen as inferior and, while the South has also sometimes been portrayed as exotic and dangerous, its inhabitants have been framed as bandits. More recently, the culturalist discourse against the South, antimeridionalisme, has fuelled the success of extreme-right separatist parties in the North. ${ }^{41}$

During the years of economic boom in the 1990s and at the beginning of the millennium, the racist imaginary remained hidden under the surface. The flood of structural funds, the diving interest rates that followed implementation of the Euro, and the relatively high growth rates in the EU overwhelmed the underlying xenophobic framework about the European periphery. For a decade, Ireland and Spain were symbols of neoliberal success. They served as policy paradigms even for right-wing nationalist forces in the central

38 Milena Lopreite, 'The Portugal situation during the financial crisis', Advances in Management and Applied Economics, vol. 1, no. 1, 2011, 111-24.

39 Liz Curtis, Nothing But the Same Old Story: The Roots of Anti-Irish Racism (Belfast: Sasta 1998); Robbie McVeigh, 'The specificity of Irish racism', Race E Class, vol. 33, no. 4, 1992, 31-45; Ronit Lentin and Robbie McVeigh, 'Irishness and racism: towards an ereader', Translocations: Migration and Social Change, vol. 1, no. 1, 2006, 22-40.

40 Fintan O'Toole, 'Green, white and black: race and Irish identity', in Ronit Lentin (ed.), Emerging Irish Identities: Proceedings of a Seminar, Held in Trinity College Dublin, November 271999 (Dublin: Department of Sociology, Trinity College Dublin 2000), 21-7.

41 Enrica Capussotti, 'Nordisti contro Sudisti: internal migration and racism in Turin, Italy: 1950s and 1960s', Italian Culture, vol. 28, no. 2, 2010, 121-38 (121-5). 
economies, such as the Nieuw-Vlaamse Alliantie (N-VA, New Flemish Alliance) in Belgium. As the boom turned out to be a bubble, however, and the still ongoing crisis saw the deterioration of political-economic conditions, anti-periphery racism resurfaced.

When societies face hard times, the figure of the stranger/outsider gets blamed for the situation and is portrayed as a threat. ${ }^{42}$ Following the great recession, the peripheral countries of the Eurozone were made scapegoats for the economic crisis and the near collapse of the Eurozone. A cultural narrative re-emerged that located the origin of the crisis in Athens and the rest of the periphery. ${ }^{43}$ It purported to explain the current situation as the effect of corrupt local politicians, the unresponsible behaviour of citizens and consumers, state inefficiency, low productivity combined with uncompetitively high wages, misuse of EU structural funds and so on.

Such 'cultural' explanations - which can be found in both the core and, to a certain extent, the peripheral countries-reproduce the classic dogma of 'blaming the victim'. It is not structural problems in the Eurozone or the global financial and economic system that is seen as the origin of the problem, but rather their victims, the populations of the debt-economies themselves. If it is not because of certain 'cultural characteristics and habits' - such as laziness, lack of productivity due to 'easy jobs' and 'retirement at 42 ', corruption, wasteful spending, inefficiency and lying, a purported 'Mediterranean mix of indiscipline, extravagance and outright corruption' ${ }^{44}$-it is because they are irresponsible, ${ }^{45}$ as well as ignorant in their choice of political representatives.

This image is contrasted with 'good', 'civilized' and 'trained' Northern European peoples who 'work dutifully up to at least 73 and 74 years old and pay more than their share of taxes for the Greek citizens' ${ }^{46}$ The duality of 'the thrifty north and lazy south' is a typical example of a negative presentation of the Other as against a positive self-presentation. ${ }^{47}$ According to Ruth Wodak, the "discursive construction of "us" and "them" as the basic fundaments of discourses of identity and difference' are therefore salient for

42 Ash Amin, 'Xenophobic Europe', openDemocracy, 9 May 2011, available at www. opendemocracy.net/ash-amin/xenophobic-europe (viewed 9 November 2015)

43 Kevin Featherstone, 'The Greek crisis', in Costas Lapavitsas (ed.), 'The Greek crisispolitics, economics, ethics: a debate held at the Birkbeck Institute for the Humanities, Birkbeck College, University of London, 5 May 2010', Journal of Modern Greek Studies, vol. 28, no. 2, 2010, 293-310 (298-301); Dorothee Bohle, The Crisis of the Eurozone, EUI Working Papers RSCAS, 2010/77 (Fiesole: European University Press 2010); Mylonas, 'Media and the economic crisis of the EU'.

44 Bohle, The Crisis of the Eurozone, 1; Lapavitsas, in Lapavitsas (ed.), 'The Greek crisispolitics, economics, ethics', 293; De Grauwe, Crisis in the Eurozone and How to Deal with It.

45 Hadjimichalis, 'Uneven geographical development and socio-spatial justice and solidarity'.

46 Lapavitsas, in Lapavitsas (ed.), 'The Greek crisis-politics, economics, ethics', 293.

47 Bohle, The Crisis of the Eurozone, 8. 
discourses of discrimination. ${ }^{48}$ In this way, pro-austerity discourse treats the European South as the undeserving poor or as colonial subjects to be reformed or civilized, ${ }^{49}$ legitimizing new forms of colonialism within the Eurozone.

Such descriptions may be blatantly racist or they may more subtly convey negative opinions. And many who resort to them will deny the racist character of their rhetoric. ${ }^{50}$ Like the Financial Times's defence of the term 'PIGS' - that it was 'a pejorative moniker but one with much truth' ${ }^{51}$ - they assume that the rhetoric is based on pure fact: laziness does lead to lower productivity, wastefulness is demonstrated by high public and private debt rates, and corruption statistics speak for themselves. One of the 'elements of truth' in the cultural explanation of the crisis - which makes the narrative work - is said to be found in the financial mess created by the Greek elite. ${ }^{52}$ And, while it is true that a considerable portion of the structural and cohesion funds in the periphery were wasted, as they were allowed to become prey to unpunished corruption and inefficient investment, ${ }^{53}$ many of the affirmations are clearly false. How, for instance, can one maintain the imaginary of 'laziness' when Spanish, Greek and Portuguese workers have longer working weeks than Germans? ${ }^{54}$ And how can Ireland and Spain be framed as spendthrifts when, before the crisis, both countries were running surpluses while Germany was running a deficit, and both had their sovereign debt lowered to 25 and 36 per cent of GDP respectively in $2007 ?^{55}$

As argued above, the effectiveness of such cultural 'explanations' lies not so much in the truthfulness of the representations of the Other, but in the depoliticization of power relations that make plausible such (mis)representations, ${ }^{56}$ ignoring the historically uneven relationships among social classes, places and

48 Ruth Wodak, 'The discourse-historical approach', in Ruth Wodak and Michael Meyer (eds), Methods of Critical Discourse Analysis (London, Thousand Oaks, CA and New Delhi: Sage 1999), 63-94 (73).

49 Costas Douzinas and Petros Papaconstantinou, 'Greece is standing up to EU neocolonialism', Comment Is Free, 27 June 2011, available on the Guardian website at www.theguardian.com/commentisfree/2011/jun/27/greece-bailout-eu-neocolonialism (viewed on 9 November 2015).

50 Evan Liaris and Harris Mylonas, 'What really went wrong in Greece?', Global Public Square, 20 November 2011, available on the CNN website at http://globalpublic square.blogs.cnn.com/2011/11/20/what-really-went-wrong-in-greece (viewed on 9 November 2015).

51 'Pigs in muck'.

52 Liaris and Mylonas, 'What really went wrong in Greece?'.

53 Santos, Portugal.

54 Heather Stewart, 'Who works the longest hours in Europe?' (datablog), 8 December 2011, available on the Guardian website at www.theguardian.com/news/datablog/ 2011/dec/08/europe-working-hours (viewed on 9 November 2015).

55 Bohle, The Crisis of the Eurozone, 7.

56 Marta Araújo and Silvia Rodríguez Maeso, 'History textbooks, racism and the critique of Eurocentrism: beyond rectification or compensation', Ethnic and Racial Studies, vol. 35 , no. $7,2012,1266-86$. 
institutions. ${ }^{57}$ The critique of the racist narrative towards the PIGS is thus not a matter of 'false' and 'erroneous' representations, but an engagement with the power relations that pervade the production of knowledge and interpretations. ${ }^{58}$

\section{Actors in the reproduction of race}

Two interrelated processes can be distinguished that have reproduced the racialization of the periphery during the Euro crisis: the electoral process and the construction of a racial media discourse. In both the core and the periphery, the actors-politicians and the media-have contributed to this reproduction process, albeit in slightly different forms.

\section{Politics}

The deteriorating economic conditions due to the global financial crisis quickly exposed the insecurity of the public finances in the peripheral economies of the Eurozone. Confronted with the unsustainability of investments by northern banks, northern policymakers were forced to intervene with bailouts and structured adjustment programmes that guaranteed - at least temporarily-the solvency of the lenders. In 2010 Greece was first forced to look for financial assistance from the International Monetary Fund (IMF) and the EU in order to guarantee its financial obligations. In the same year Ireland also was granted $€ 85$ billion and, in April 2011, it was Portugal's turn to accept $€ 78$ billion of 'aid'. Spain has managed to limit the harsh conditions placed on the aid through the negotiation of an agreement that does not bail out the state, but only its banks, but is nevertheless subject to the harsh austerity reforms framed in the six-pack reform package. ${ }^{59}$

While the bailouts mainly served to guarantee payments to the investors in the northern banks, in which the peripheral states only served as intermediaries, the situation was portrayed as if the Greeks 'wanted' a bailout from 'hard-working Germans' and German citizens felt they had to bleed for Greek sins. ${ }^{60}$ The 'aid' was thus perceived as a transfer from core workingclass taxpayers to peripheral corrupt states and their 'lazy, lying' populations. Here the cultural discourse re-entered the political debate as a moral

57 Hadjimichalis, 'Uneven geographical development and socio-spatial justice and solidarity'.

58 Brown, 'Tolerance as a discourse of depoliticization'.

59 See the timeline originally prepared by Christophe Gouardo and Jean Pisani-Ferry and updated by Breughel in 'Euro crisis' (blog) 16 September 2015, available on the Breughel website at http://bruegel.org/2015/09/euro-crisis (viewed 9 November 2015). 
legitimation of the imposed budgetary austerity. The cultural arguments backfired, however, when they were afterwards used by populist right-wing opposition leaders in core countries to delegitimize the European aid itself.

These populist arguments spread quickly among voters. They perceived the effect of the economic crisis and the economic restructuring policies as an attack on their living standards. The 'lazy PIGS' stereotype worked here as 'the Jew' stereotype worked in the 1930s, in the sense that its discursive construction blamed the PIGS for the crisis and made a confusing situation readable. ${ }^{61}$ This sparked a spiralling dynamic in which the potential success of the populist players redoubled the determination by core leaders to adopt a tough line in their own rhetoric so as not to lose votes. This in turn strengthened the racial rhetoric and, with it, the growing racialization. Examples can be found in the case of the Dutch government and the opposition of Geert Wilders and the Partij voor de Vrijheid (PVV, Party for Freedom), ${ }^{62}$ the French government and the right-wing opposition of Le Pen and the Front national, the ChristlichSoziale Union (CSU, Christian Social Union), a staunchly conservative fraction of Angela Merkel's party, the Christlich Demokratische Union (CDU, Christian Democratic Union), as well as the surge of different Eurosceptic parties such as United Kingdom Independence Party (UKIP), the Alternative für Deutschland (AfD), the Perussuomalaiset (Finns Party) and so on.

What is more surprising is that a similar political process took place in the peripheral countries. Their governments' initial unconditional allegiance to neoliberal principles and the conditions placed on the austerity packages had depoliticized the debate around the crisis, at least among the traditional mainstream parties. By framing the policy measures in a technocratic way and by forcing a 'national consensus' in support of the Troika - the European Commission (EC), the European Central Bank (ECB) and the IMF-the structural causes of socioeconomic hardship were made invisible and political leaders accordingly reinforced the racialized framework. This process was bolstered by the way the traditional parties engaged in electoral competition. The depoliticized electoral rhetoric emphasized the need for 'responsible' policies with regard to the Troika. By accepting and defending the need for international 'aid' and the legitimacy of the austerity packages, policymakers admitted that the populations of the PIGS had been wasteful and irresponsible. Copying the rhetoric that these countries were 'living above "their means"', the inter-party consensus adopted the racial framing of the Euro crisis.

In many cases opposition discourses also strengthened the culturalist framework. In Portugal, for example, the Partido Social Democrata (PSD, Social Democratic Party) won the 2011 election on a campaign that blamed the

61 Slavoj Žižek, The Parallax View (Cambridge, MA and London: MIT Press 2009).

62 Niek Stolker, 'Geert weet ook wel dat de gulden niet terugkomt. Hij wil alleen stemmen winnen', HP/De Tijd, 11 November 2011, available on the HP/De Tijd website at www.hpdetijd.nl/2011-11-11/geert-weet-ook-dat-de-gulden-niet-terugkomthij-wil-alleen-stemm/ (viewed 9 November 2015). 
extravagance, mismanagement and corruption of the Socrates government for the crisis. At the same time, left-wing opposition movements demanded 'an audit' to determine what was 'legitimate' debt and 'illegitimate' debt, implying that at least part of the debt problem was a question of mismanagement. A new, small populist party on the radical left, Movimento Alternativa Socialista (MAS, Alternative Socialist Movement), advocated the 'arrest of those who robbed our country' as part of its 2013 campaign. These opposition discourses, particularly when they focus on 'corruption' and 'political privilege' as the main causes of 'bad governance', individualize and culturalize the crisis and, in turn, legitimize the hypothesis of a 'corrupt culture' as the root of the problem.

Another example is the apparent 'intra-peripheral' competition between the PIGS in which policymakers try to convince their voters, the EU and the financial markets that their country is 'different': 'Ireland is not like Greece', 'Portugal is not Ireland'. Politicians of the PIGS have all participated in this kind of blame game, implying that their country forms an exception to the rule of the South, ${ }^{63}$ thus reinforcing prejudices against the other PIGS and the South in general. The Portuguese minister of foreign affairs Paulo Portas recently exemplified this in a speech when he claimed that it is necessary that people know there is one country in the South where people are industrious' ${ }^{64}$

\section{Media}

The other major actors involved in reproducing a racialized frame were the corporate, mostly northern, media outlets. Media discourses always play a major role in the reproduction of racism. In otherwise too complex societies, mass media are the primary source of digestible knowledge. News media, however, do not passively describe or record news events. They actively reconstruct them on the basis of corporate interests, professional ideologies and institutional routines. ${ }^{65}$ In the case of the 'story' of the Euro crisis, the racialized framework of the PIGS articulates perfectly with the hegemonic neoliberal media discourse of recent decades as well as with the corporate class interests of the owners of the media concerns.

63 Mustafa Kutlay, 'Stopping "blame game", revealing the Euro zone's design faults: complex interdependence within the nation-state framework', Uluslararasi Hukuk ve Politika, vol. 7, no. 27, 2011, 87-111.

64 Quoted in André Cabrita Mendes, 'Portas: “É preciso que se saiba que há um país no sul cuja gente é trabalhadora"', 21 April 2014, available on Dinheiro Vivo website at www.dinheirovivo.pt/economia/portas-e-preciso-que-se-saiba-que-ha-um-pais-no-sulcuja-gente-e-trabalhadora (viewed 9 November 2015).

65 Teun A. van Dijk, 'Mediating racism: the role of the media in the reproduction of racism', in Ruth Wodak (ed.), Language, Power and Ideology: Studies in Political Discourse (Amsterdam and Philadelphia: John Benjamins 1989), 199-226. 
Yiannis Mylonas has analysed this extensively in the German tabloid press, in particular in Bild-Zeitung. ${ }^{66}$ The story consistently aired is simple enough: 'Greece, we are told, free-rode on the security offered by the rest of Europe to attract money from foreign investors, and then spent it lavishly on its bloated public sector. ${ }^{67}$ In January 2010, for example, Bild-Zeitung published an article supposedly containing 'the basic facts about Greek corruption' under the title 'Ohne Schmiergeld läuft in Griechenland fast nichts mehr' (without bribes nothing works in Greece). ${ }^{6}$ Such articles incited public opinion against the Greeks by reproducing the stereotype of lazy Mediterranean people conning their hard-working North European partners before shamelessly asking for a bailout. ${ }^{69}$

While this paper does not allow for a full discourse analysis of this issue, a few examples of similar discourses on the South European crisis in other core outlets of the German, English, Belgian and American media will show the range of issues involved. The German weekly magazine Focus, for example, published an issue on 20 February 2010 with a cover title Betrüger in der Eurofamilie, which means something like 'the liars/deceivers of the Euro family' ${ }^{70}$ The Guardian, a progressive British mainstream daily, published an article by Philip Inman including the following: '... Italian workers have paid themselves more than their German equivalents over the past ten years for doing less work, less productively ... ${ }^{71}$ On 1 April 2011, the same paper printed an article under the heading: 'Ireland hopes fifth bailout will end the years of corruption and greed: taxpayers have borne the cost of the country's failure to face up to the truth' (emphasis added). It is here implied that the country's problem is primarily one of greed and that British bankers and politicians would be less greedy and less corrupt than Irish ones. ${ }^{72}$

Another illustration can be found in a personal opinion piece by Patrick Soetens in the Belgian financial newspaper De Tijd. Soetens, a Geneva banker, wanted to pinpoint 'the cultural factor' (sic) that caused the Euro crisis and the divergent behaviour of the Greeks and the Irish regarding the

66 Mylonas, 'Media and the economic crisis of the EU'.

67 Liaris and Mylonas, 'What really went wrong in Greece?'.

68 Oliver Santen, 'Ohne Schmiergeld läuft in Griechenland fast gar nichts mehr', BildZeitung, 31 January 2010, available on the Bild website at www.bild.de/politik/ wirtschaft/griechenland/ohne-schmiergeld-laeuft-fast-gar-nichts-mehr-11312616.bild. html (viewed on 10 November 2015).

69 Bohle, The Crisis of the Eurozone, 1.

70 Christos Katsetos, ‘Betrüger in der Eurofamilie' (blog), 24 February 2010, available on the Akritas Macedonian blog website at http://modern-macedonian-history.blogspot.co. uk/2010/02/betruger-in-der-euro-familie.html (viewed 10 November 2015).

71 Guardian, 5 November 2011, quoted in John Weeks, 'Breaking news: the working class caused Italian crisis' (blog), Social Europe Journal, 10 November 2011, available at www.socialeurope.eu/2011/11/breaking-news-the-working-class-caused-the-italiancrisis (viewed 10 November 2015).

72 Lisa O'Carroll, 'Ireland hopes fifth bailout will end the years of corruption and greed', Guardian, 1 April 2011. 
imposed austerity measures. According to the author, the causes lay in the fact that 'every Greek took part in a corrupt state at a personal level' while Ireland was 'ruined by ten foolish years of unrestricted growth and equal greed'. The outrageous 'angry Greek resistance' is sarcastically attributed to the Greek 'self-image as the only real cradle of European civilization'. According to Soetens, the 'big Greek self-image was totally distinct from the economic reality' and, instead of anger, the Greeks should have shown 'shame and acceptance'. They should have looked to the Irish who understood that they had to 'turn back to their traditional Irish values that had given way to greed and materialism'. Although the author probably thought he was only denouncing the Greeks, he was in fact racializing both the Greeks and the Irish, 'their problems' and 'their behaviour'. The Irish were constructed as 'good, nearly childish, uncivilized' and the Greeks as 'evil uncivilized' ${ }^{73}$

Across the Atlantic, Ralph Minder in the New York Times characterized Portuguese donkeys as 'neglected', 'misunderstood' and 'dependent on . . . subsidies from the European Union'. ${ }^{74}$ In another article, headed 'SPAIN, LAND OF 10 P.M. DINNERS', Jim Yardley states: 'Spain still operates on its own clock and rhythms. But now that it is trying to recover from a devastating economic crisis . . . a pro-efficiency movement contends that the country can become more productive, more in sync with the rest of Europe, if it adopts a more regular schedule. ${ }^{75}$

\section{Neocolonialism}

Depoliticization and racist ideology have a historical link to processes of colonization. Boaventura de Sousa Santos theorizes these relationships in his concept of abyssal thinking, ${ }^{76}$ based on the abyssal line, the deep sea that existed between former colonizers and their colonies. Santos argues that such a line remains within contemporary thought, distinguishing metropolitan societies from colonial territories. It works as a metaphor to describe the ideological or epistemological process that makes the universe on the other (colonized) side vanish, that renders it irrelevant or incomprehensible. Visibility is a fundamental aspect of the process of racialization. According to Andrea Brighenti, visibility not only divides marked and unmarked people - resulting in a universal reference point that structures the meaning of particular cases-but this division between the visible and the invisible also

73 Patrick Soetens, 'Ieren ontvankelijker voor schuld en boete dan Grieken', De Tijd, 14 February 2012.

74 Raphael Minder, 'Hard times for a small (and fuzzy) group of Europeans', New York Times, 29 November 2013.

75 Jim Yardley, 'Spain, land of 10 p.m. dinners, asks if it's time to reset clock', New York Times, 18 February 2014.

76 Boaventura Sousa Santos, 'Para além do Pensamento Abissal: Das linhas globais a uma ecologia de saberes', Revista crítica de ciencias sociais, no. 78, October 2007, 3-46. 
structures a power relation. ${ }^{77}$ The real causes of the problems of the PIGS become 'invisible', and what remains visible-cultural differences that stand as explanations for the crisis-reinforces racialization. The abyssal line limits principles, such as virtue, autonomy, equality, utility and rights, in various ways, to the core economies and 'good productive white people'. ${ }^{78}$ This limitation leaves the Others in conditions that are clearly inimical to the fundamental moral principles of the metropolitan centre, such as democracy, rights, equal treatment, justice and fairness.

As abyssal thinking makes the problems of the colonized incomprehensible, they are dealt with by appropriation and violence. ${ }^{79}$ Unsurprisingly, Santos argues that, in the case of the European periphery, there has been a return of the colonizer, resurrecting forms of colonial rule, ${ }^{80}$ an opinion shared by Costas Douzinas and Petros Papaconstantinou. ${ }^{81}$ Within the context of the crisis, the renewed European colonizers have taken over control of the PIGS' sovereignty through the re-emergence of colonial-like indirect rule in the form of the Troika and massive privatizations. These policies have made the sovereign entity withdraw from social regulation and public services. The Rechtsstaat, a concept on the metropolitan side of the abyssal line, has been replaced by private contract obligations in which the weak are at the mercy of the strong. ${ }^{82}$ Policymakers at the core have demanded assimilation of their policies. When their violent dictates are not met, the populations are confronted with ever greater social conflict and austerity, causing levels of hunger and human degradation previously unthinkable in the 'civilized world'.

Should such a situation be characterized as neocolonial? In his work, Neocolonialism: The Last Stage of Imperialism (1965), Kwame Nkrumah identifies a number of neocolonial strategies, including 1) domination of the economy by monopolies of the core countries; 2) domination of 'free trade' by western monopolies; 3 ) the charging of high interest rates by core banks to peripheral countries; 4) 'multilateral aid' through international organizations, particularly the IMF, with harsh conditions and supervision by these institutions; and 5) widespread and wily use of ideological and cultural weapons combined with hegemonic control through the control of media. ${ }^{83}$ Although this framework was primarily conceived for understanding the situation of so-called 'Third World' countries following decolonization, it shows

77 Andrea Brighenti, 'Visibility: a category for the social sciences', Current Sociology, vol. 55, no. 3, 2007, 323-42.

78 Santos, 'Para além do Pensamento Abissal'.

79 Ibid.

80 Boaventura de Sousa Santos, 'O desenvolvimento do subdesenvolvimento', 20 October 2011, available on the Visão website at http://visao.sapo.pt/odesenvolvimento-do-subdesenvolvimento=f628598 (viewed 11 November 2015).

81 Douzinas and Papaconstantinou, 'Greece is standing up to EU neocolonialism'.

82 Santos, 'Para além do Pensamento Abissal'.

83 Nkrumah, Neo-Colonialism. 
considerable usefulness with regard to the peripheral countries in the Eurozone today.

Apart from the role of the media and cultural hegemony in the reproduction of racism towards the PIGS, already discussed above, some of Nkrumah's strategies are evident, such as charging high interest rates. Since the beginning of the sovereign debt crisis, all of the PIGS have been struggling with this situation. Their interest rates reached levels so high that they were on the brink of bankruptcy. This becomes particularly clear when we compare the interest rates that debt-ridden countries had to pay on the markets or even to the European Financial Stability Fund (EFSF) with those banks have to pay when borrowing money from the European Central Bank. Portugal, for example, had to pay 13.8 per cent on the markets and 5.0 to 5.7 per cent to the EFSF (with harsh conditions), compared to the banks paying an ECB rate of 1.0 per cent.

Foreign companies are somewhat more difficult to compare using Nkhruma's description of neocolonialism. The processes of economic liberalization, globalization and free movement of capital have somewhat muddled the 'nationality' of companies. If 'foreign companies' are defined as 'companies who are not subject to the national control of the peripheral countries', then the situation is very clear. Weaker nations in particular, like the PIGS, have lost control over these companies. The crisis and the consequent structural reforms have increased the deep penetration of traditionally core-based companies in the PIGS' economies, illustrated, for example, by the negative trade balances of the PIGS versus the core, Germany in particular. ${ }^{84}$ The loss of control is also evident in the transfer of the official headquarters of the PIGS' own historical companies to the core: 17 of the 20 companies in the PSI-20, the Portuguese stock market, for example, have their headquarters in the Netherlands. ${ }^{85}$ Moreover 'free' trade-the aim of the EC-is dominated by these kinds of large non-national companies.

Multilateral 'aid' is probably the clearest 'neocolonial method' in the case of the Eurozone. During the last decades numerous peripheral countries of the world-system found themselves in a situation in which a financial crash obliged them to accept multilateral aid from the IMF and the World Bank. In these cases, those institutions took control of the management of the countries, implementing structural adjustment programmes and abolishing public accountability. Portugal, Greece and Ireland found themselves in a similar situation in the process of the Eurozone crisis.

The Euro crisis forced the core countries to 'help' the periphery. Two things should be said about this. First, the EU proved unable and unwilling to handle the crisis by itself. Only when the crisis transcended the particular case of

84 John Weeks, 'Euro crises and euro scams: trade not debt and deficits tell the tale', Review of Political Economy, vol. 26, no. 2, 2014, 171-89.

85 Ana Rute Silva, 'Holanda recebeu mais de $80 \%$ do investimento directo de Portugal', Público, 9 October 2011, available on the Público website at www.publico.pt/economia/ noticia/holanda-recebeu-mais-de-80-do-investimento-directo-de-portugal-1515627 (viewed 11 November 2015). 
Greece, and the core banks might be under threat, was a 'solution' found. ${ }^{86}$ The bailouts should never be seen as a gift: they were not designed to guarantee the ability to pay civil servants' salaries and social expenses. They were designed to save the countries with solvency problems temporarily in order to guarantee the debt held by German and French banks. ${ }^{87}$ The 'aid' allowed Germany and France to design an indirect bailout mechanism. By bailing out the peripheral states, it forced German and French workers to bail out their own banks, not directly as in the 2008-9 bank bailouts, but through the mediation of Greece and the other PIGS. ${ }^{88}$

An important second aspect of this kind of 'aid' and the European 'solidarity' between the centre and the periphery is that it comes with heavy strings attached and harsh conditions. ${ }^{89}$ The Greek 'help plan' was the first example of the shock doctrine applied in Europe, a situation only made acceptable in 'civilized' societies by the atmosphere of emergency. ${ }^{90}$ With breathtaking speed, a hardline neoliberal elite consensus was formed. According to this consensus, the aid-receiving countries needed to trim their public sectors and retrench their welfare programmes. As an alternative to currency devaluation-impossible in the currency union-the PIGS were forced to undergo a so-called internal devaluation, with deep cuts in wages and public spending.

The debtor nations were put in a position of 'colonial submission' ${ }^{91}$ The loss of economic sovereignty came with an attack on the political and economic integrity of the country. National parliaments lost control over national budgets, as budgets had to pass through a European commission even before they entered parliamentary deliberation. ${ }^{92}$ The payment of subsequent loan instalments was continuously used as a form of blackmail to impose new austerity measures, not only against the governments, but also against the oppositions. ${ }^{93}$ In what is described by Étienne Balibar as a 'kind of dictatorial process' ${ }^{94}$ these measures were imposed without any democratic discussion. Any remaining traces of democratic decision-making vanished with the involvement of European leaders in the replacement of President Berlusconi in Italy and Prime Minister Papandreou in Greece, as well as the blackmailing of Greece to cancel a referendum on austerity in November 2011.

86 Hadjimichalis, 'Uneven geographical development and socio-spatial justice and solidarity'.

87 Lapavitsas, in Lapavitsas (ed.), 'The Greek crisis-politics, economics, ethics'.

88 Douzinas and Papaconstantinou, 'Greece is standing up to EU neocolonialism'.

89 Bohle, The Crisis of the Eurozone, 5.

90 Stathis Kouvelakis, 'The Greek crisis', in Lapavitsas (ed.), 'The Greek crisis - politics, economics, ethics', 303-6.

91 'Germany plans for what comes next', Financial Times, 13 July 2010; Bohle, The Crisis of the Eurozone, 6.

92 Bohle, The Crisis of the Eurozone, 6.

93 Douzinas and Papaconstantinou, 'Greece is standing up to EU neocolonialism'.

94 Étienne Balibar, 'The Greek crisis', in Lapavitsas (ed.), 'The Greek crisis-politics, economics, ethics', 306-9. 
These 'strings' are remarkably similar to those attached to the conditional development aid given to the Global South. As Nkrumah argued, the cover of 'aid' allows 'innumerable ways to accomplish objectives formerly achieved by naked colonialism'. After having 'granted' independence to its former subjects, 'these modern attempts to perpetuate colonialism, while at the same time talking about "freedom" . . . have come to be known as neo-colonialism" ${ }^{95}$

Today's neocolonial tendencies within the Eurozone do not exist in a historical void. As is the case with racism towards the peripheral countries, there is a history of colonial and neocolonial relations between the core and the periphery in the European zone. Portugal, for example, has a long history of semi-colonial subordination to the central countries of Europe, the United Kingdom in particular. ${ }^{96}$ From the 1640 s, it was increasingly incapable of developing a balanced economy. Consequently, British control over the Portuguese economy tightened and the country and its own colonies became an informal type of colony, the cheapest and most productive type for the British Empire. ${ }^{97}$ Its dependent position was finally institutionalized during the Berlin Conference and the ensuing 'scramble for Africa' in 1884, when it was de facto excluded from decisions about the international regime that would structure European colonialism during the following decades. ${ }^{98}$ Being in a colonized position prevented Portugal, and to a lesser extent Spain, from forming an independent national bourgeoisie with its own national project, keeping the country dependent on the central European countries. Since the 1980s, the EU project has promised the opportunity to become a member of the core of the capitalist world-system. It seemed to offer an escape from Portugal's historical inability to develop its own national bourgeoisie and a fully developed national capitalist economy. Boaventura de Sousa Santos, for example, has argued that, in the case of Portugal, EU membership has meant that the country needn't bother anymore about the lack of a bourgeois revolution and could rid itself of any negative consequences. ${ }^{99}$ The current Euro crisis, however, has proved this opportunity to be a false dawn, with a serious loss of sovereignty as a result.

\section{A barrier to a solution}

This article has focused on the interaction between racist discourses and the return of colonialism in the political economy of the Eurozone. It shows a strong connection between the processes of racialization and the depoliticization-characteristic of hegemonic neoliberalism-and the internal processes

Nkrumah, Neo-Colonialism, 1.

Santos, Portugal.

97 Dauril Alden, review of S. Sideri, Trade and Power (1970) and H. E. S. Fisher, The Portugal Trade (1971), Journal of Economic History, vol. 31, no. 4, 1971, 990-3.

98 Santos, Portugal.

99 Ibid. 
of uneven geographical development. These interactions have become particularly clear during the recent crisis of the European Monetary Union. Today's racist discourses and neocolonial politics have their roots in the past: in anti-Irish and anti-Mediterranean racisms as well as in the (semi-)peripheral position of the PIGS in the British and Ottoman empires. The re-emerging forms of racism, however, are reproduced in political and media discourses as a result of the interlinked dynamics of post-political neoliberal hegemony, populism and corporate interests.

The contemporary forms of racism serve as the ideological justification for new forms of colonialism within the EU. The crisis has forced Northern European countries to intervene in the economies of Southern European countries. Their interventions show remarkable similarities with neocolonial strategies in Africa used after official decolonization and described by Kwame Nkrumah. ${ }^{100}$ Particularly salient is the case of 'development aid' and the discourses around it that legitimize the loss of popular sovereignty and democracy. The neocolonial treatment that the peripheral countries have received clearly contradicts the primary principles of what is portrayed as the European moral 'enlightenment', such as democracy, rights, equal treatment, justice and fairness. Racialization and culturalization is used to limit principles, such as virtue, autonomy, equality, utility and rights, to the core economies and 'the good productive white people'. By enabling racialized expression, discriminatory exclusions can effectively be authorized on the basis of the principle of moral reason itself. ${ }^{101}$

Federalist critiques of EU governance, such as that by Paul De Grauwe, ${ }^{102}$ have proposed further political integration as an alternative to the crisis. They explain the Euro crisis as the result of an independent monetary authority without an economic government. A common economic policy would be a solution to the divergence provoked by a unified interest rate policy with different economic conjunctures. The problem of the EU is that, to work efficiently as an entity within the capitalist world-system, it needs to work like a nation-state: the historical institution that evolved on the national level as a response to uneven geographical development. The nation-state is the institutional result of social struggles that created instruments of integration able to legitimize wealth transfers-including official citizens' rights, integration through forms of participation and accountability, and the formation of a common identity - and at the same time created physical, legal and cultural boundaries to this integration. The periphery of the EU seems to be caught in a permanent struggle with similar, though more contingent, boundaries, and the consequence of the re-emergence of racialization and colonial dynamics in crisis times jeopardizes any possibility of a shared

100 Nkrumah, Neo-Colonialism.

101 Goldberg, 'Modernity, race, and morality'.

102 De Grauwe, Crisis in the Eurozone and How to Deal with It. 
national-like identity that might serve as an ideological basis for a politicaleconomic union and as a 'solution' to the crisis.

Jonas Van Vossole is a Ph.D. candidate at the Centre of Social Studies, an Associated Laboratory of the University of Coimbra, and at the Department of Political Science of the University of Ghent. His dissertation is on the influence of the Euro crisis on democratic legitimacy in Southern Europe, particularly in Portugal. His main research interests are the study of democracy, social movements, social protests and critical political science and political economy. $\mathrm{He}$ is an associate researcher for Ghent Association for Studies on Parties and Representation (GASPAR) and a member of the European Consortium for Political Research (ECPR) standing groups on South European Politics and on Democratic Innovations. Email: jonas.vanvossole@ugent.be 